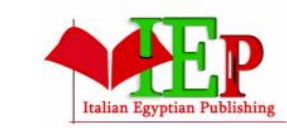

ISSN: $2735-4415$
INTERNATIONAL JOURNAL OF

MULTIDISCIPLINARY STUDIES IN ARCHITECTURE AND CULTURAL HERITAGE

VOLUME 2, ISSUE 1, 2019, $67-104$.

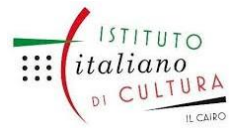

www.egyptfuture.org/ojs/

\title{
Highlights on the Deterioration of Rock Art at Unfinished Obelisk Quarry in Aswan-Egypt
}

\author{
Abd El-Hakim A. El-Badry a, *, Mona F. Ali b, Nasser G. Abd El-Ghafour c \\ a Ministry of Antiquities, Luxor, Egypt \\ b Department of Conservation, Faculty of Archaeology, Cairo University, Egypt \\ c Department of Raw Building Materials \& their processing, HBRC, Cairo, Egypt
}

\begin{abstract}
The unfinished obelisk quarry in Aswan is one of the most important archaeological sites in Egypt. This site contains very important rock art panels (paintings and inscriptions) which give the site further importance and are concerned with the activities of the quarry. Rock art panels at this site are subject to different kinds of physical, chemical and biological deterioration as a consequence of their exposure to the direct action of aggressive atmospheric agents (extreme temperature, wind, chemical weathering, salts pressure and the rising water table from the canal at the site) and anthropogenic deterioration factors so; they suffer from different deterioration phenomena such as exfoliation, granular disintegration, detachment, salt crystallization, aesthetic disfigurement and chemical alterations. For this purpose, the chemical, physical and structural characterization were performed by means of Polarizing Microscope (PM), Scanning Electron Microscope (SEM) attached with EDX, X-Ray Diffraction (XRD), Infrared analysis (I.R) and microbiological study. The results have shown that these panels suffer from many crystallized salts such as sodium chloride and calcium sulphate (anhydrite or gypsum) and alteration of
\end{abstract}




\begin{tabular}{ll} 
feldspars to clay minerals. \\
\hline Keywords \\
$-\quad$ Rock Art \\
- & Rock Inscription \\
- & Unfinished Obelisk \\
- & Aswan \\
- & Granite \\
- & Deterioration \\
- & Vandalism \\
- & Physical Enhancement
\end{tabular}

\section{Introduction}

Rock art is a term normally applied to paintings and engravings on natural rock surfaces (1). The unfinished obelisk lies in the northern granite quarries at Aswan (Fig. 1a,b,c) and this quarry is a site of tremendous importance, being one of the most impressive quarries in the world and a monument over ancient Egyptian technology, yet not completely understood (2). It derives its name from the fact that a colossal obelisk (dating to the eighteen dynasty, the reign of Hatshepsut or Thutmose III) was abandoned at an advanced stage in the process of extraction due to faults or cracks in the stone (3). This site not only 
supplied the Ancient Egyptians with raw materials to erect theirtemples, tombs, colossi and obelisks (Fig.2(a)) all over the history but also contains very important rock art panels (paintings and inscriptions) which give the site further importance and are concerned with the activities of the quarry and had a direct relationship to the life in the quarry in the ancient times. The results of the excavations carried out by the Supreme Council of Antiquities, Aswan office in 2002 provide that, many new discoveries such as quarry tools, different techniques of stone extraction, unfinished objects and the most famous is discovering rock art panels, all these rock art panels located above granitic bedrock face extends for about 45 meters. $(4,5)$ divided rock art in the site generally to the follow images; A group of dolphins or fishes? In different sizes (Fig.2 (b)) although most Egyptologists identified that figures represent dolphins. Hawss; considered them kind of fish called Thamus, well known and still to be found in Lake Nasser. A group of ostriches, standing persons holding sticks (Fig.2(c,d)) obelisks and boats; the standing obelisks in different levels and sizes whilesome of these boats appear to be carryingobelisks or large blocks of granite ,Bes (the dwarf deity) depicted to protect and entertain the workers during the hard work in the quarry, geometric figures, group of work level lines and hieratic dates; both are method of calculating daily excavation and related to the ancient Egyptian calendar. In addition to the 
previous rock paintings, the quarry contains rock engravings represented in the inscription of Thutmose III, which containing the royal decree to cutting obelisks from the quarry in year 25 of Thutmose's reign, and scratch marks are related to the ancient Egyptian calendar. 


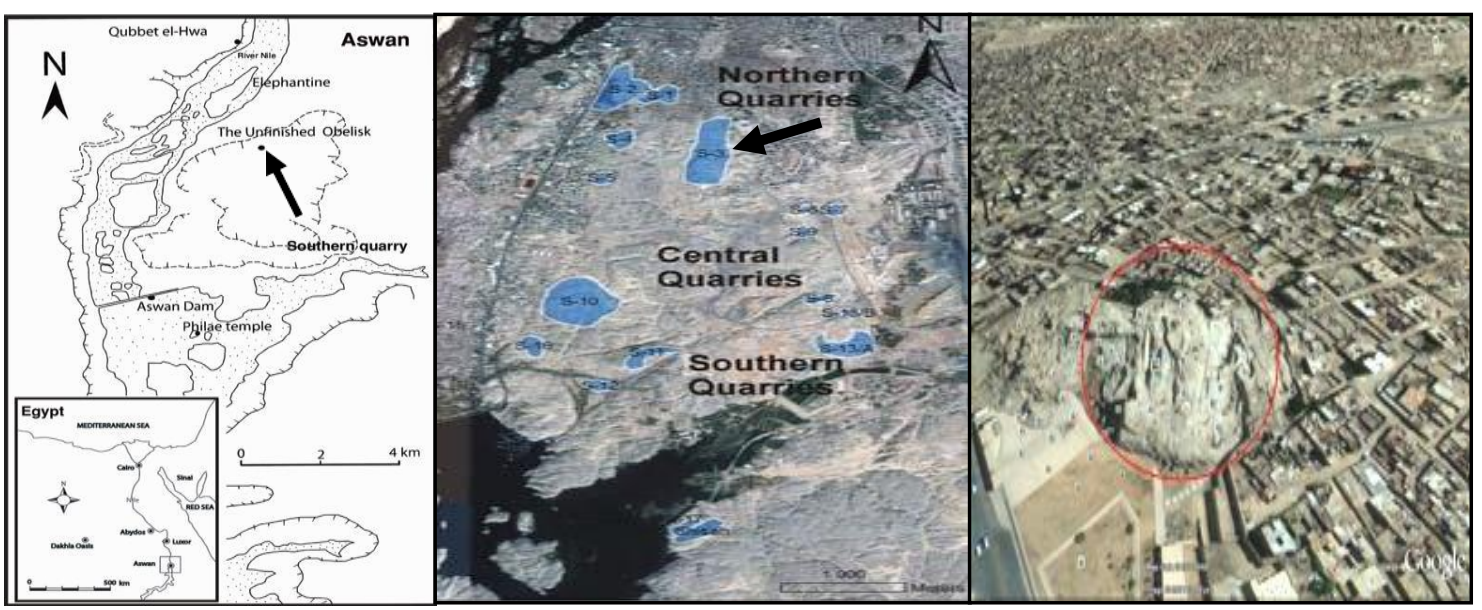

\subsection{Conservation State:}

Rock art panels at unfinishedobelisk had been exposed to either burial, aerial (exogentic) environments and endogenetic factors, whereas endogenetic related to the physical, mechanical, and chemical properties of the rock itself, and exogentic factors include environmentalagents such as wind, sunlight, temperature, moisture, rain vegetation, biotic, human being 
agents, in addition to the rising ground water table from the canal at the site (Fig.3 (a-f)) which helps the water and moisture to penetrate along the vertical, horizontal fractures and cracks in granitic bedrock and caused severe damage for rockart such as; Salt efflorescence, growing the vegetation and higher plants, furthermoreanthropogenic deterioration factors play an important role in the deterioration of rockart through application of some substances to increase photographic contrast between the scenes and rock substrate (surface) during the documentation process, which is called the physical enhancement (6) some of these materials include the use of water and chalk, both of them have been used for documenting the rock art at unfinished obelisk quarry and they caused a serious damage, fading the rock surfaces and destroying the radiocarbon dating.

Another factor of anthropogenicdeterioration is that, quick discovery and sudden exposure for rock art panels during excavations from burial to aerial environment, both have a different conditions and caused the deterioration resulted in environmental shock. The quick discovery caused quick dryness for panels from moisture and its water content, causing the fading of the paintings and salt crystallization forms such as efflorescence...etc. The third anthropogenic deterioration factor represented in using inappropriate treatment with a solution of Paraloid B 72 for consolidation the support of rock art (wetted granite) directly after its discovery from burial environment 
All the previous conditions lead to a lot of deterioration forms of rock art at unfinished obelisk quarry in Aswan (Fig.4 (a-d)) such as exfoliation, granular disintegration, detachment, salt crystallization, aesthetic disfigurement and chemical alterations. Aesthetic disfigurement through deposit minerals on the surface that may cover the art and appearance of white and grey or black areasor rain channels on rock art panels due to rains or runoff water (8) which also dissolves soluble pigments, causing paintings to fade (9) more than that thiswater can also dissolve minerals and precipitate salts on or near the surface (10). These salts contribute to the weathering of rock art through thermal expansion, hydration and crystallization pressures (11) in the form of detachment scales of superficial stratum of rock art as a result of sub florescence, that is the most dangerous kind of salt crystallizations (12) salts could be lead to loss of some rock paintings details due to quick evaporation of saline solutions with aid of sand-blasting by wind.

Granite has a low thermalconductivity (13). Barton, 1916 noted that the temperature of the granite surface in Aswan reached near to $80^{\circ} \mathrm{C}$ during thesummer (14), that led to weathering processes through thermal shock and thermal stress fatigue, through repetition on a diurnal or seasonal 
INTERNATIONAL JOURNAL OF

MULTIDISCIPLINARY STUDIES IN ARCHITECTURE

AND CULTURAL HERITAGE

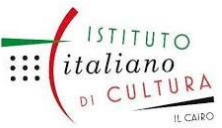

scale, this caused the granular disintegration or the production of new fractures in the support of rock art $(15,16)$.

Fig.3 Deterioration factors affecting rock art at unfinished obelisk quarry:
(a) Rising of ground water table.
(b) Vertical and horizontal fracture in the panels.
(c) Salts efflorescence.
(d) The vegetation and higher plants.
(e) Wrong documentation using chalk.
(f) Inappropriate treatment using Paraloid B 72. 
INTERNATIONAL JOURNAL OF

MULTIDISCIPLINARY STUDIES IN ARCHITECTURE

AND CULTURAL HERITAGE

istituto
$\vdots: \vdots\left(\begin{array}{c}\text { italiano } \\ \text { ol CULTURA }\end{array}\right.$

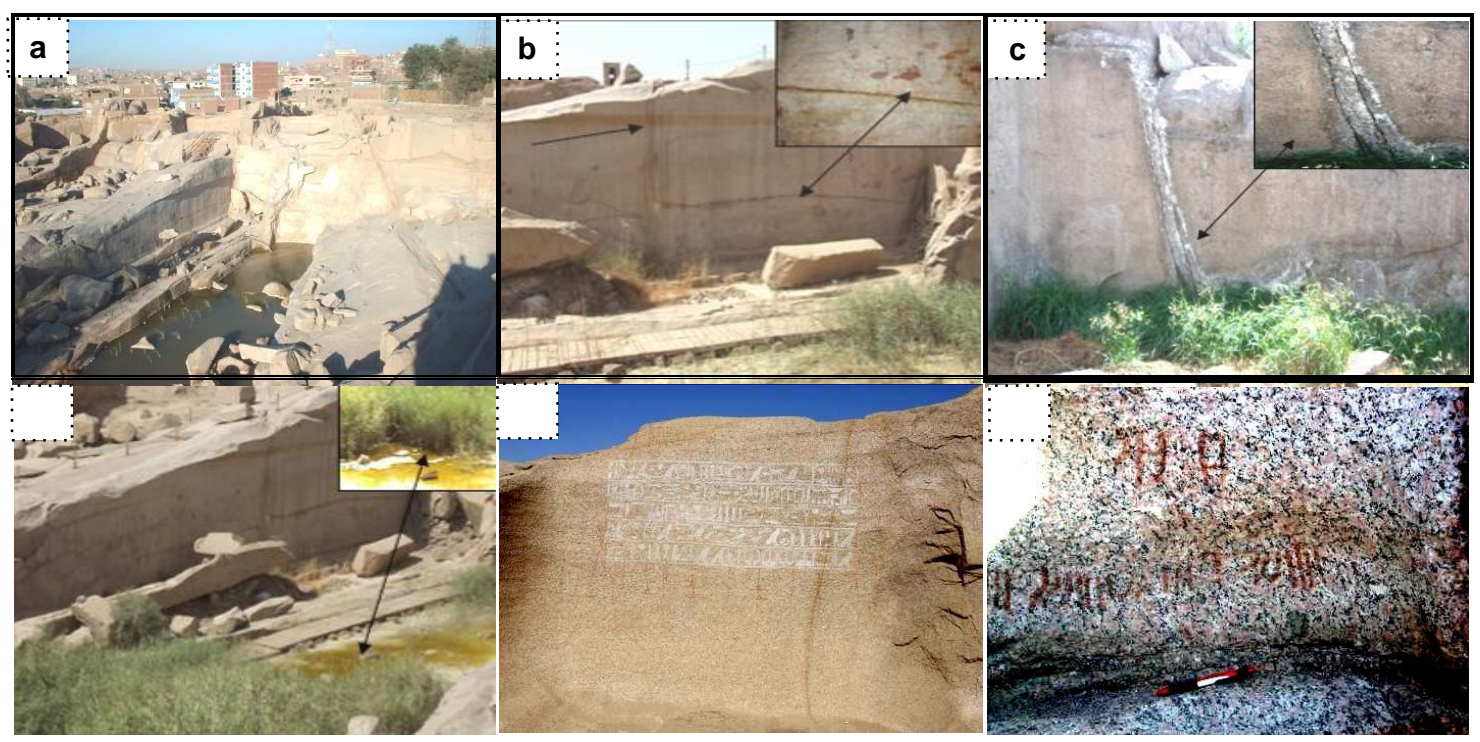


INTERNATIONAL JOURNAL OF

MULTIDISCIPLINARY STUDIES IN ARCHITECTURE

AND CULTURAL HERITAGE

ISSN: $2735-4415$

VOLUME 2, ISSUE 1, 2019, 67 - 104.

www.egyptfuture.org/ojs/

\begin{tabular}{|l|l|l|}
\hline \hline d & e & f \\
& & \\
& & \\
\hline
\end{tabular}


INTERNATIONAL JOURNAL OF

MULTIDISCIPLINARY STUDIES IN ARCHITECTURE

AND CULTURAL HERITAGE
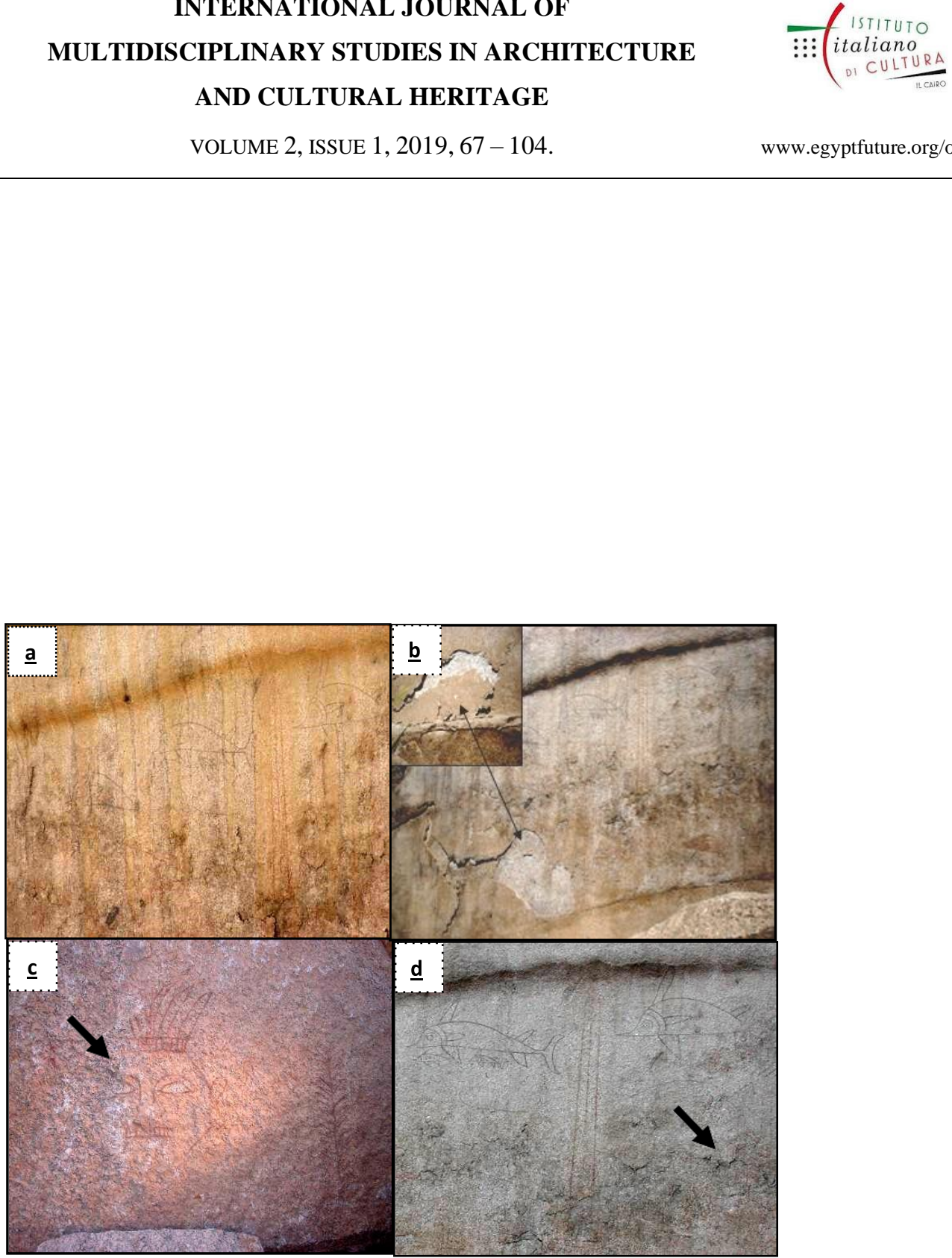

Fig.4 Deterioration forms of rock art at unfinished obelisk quarry at Aswan:

(a) White and black areas due to rains. ( b) Detachment of thin outer layer of rock art support. 
Materials and Methods

Some weathered samples of granite and paintings flakes from rock art surfaces at unfinished obelisk quarry were studied by scientific methods; Polarizing Microscope (PM) Scanning Electron Microscope attached with Energy dispersive X-ray analysis (SEM-EDX), X-ray diffraction (XRD) to identifying their mineralogical, chemical components, alteration features and deteioration products, in addation to deteriming the painting media. Biodeterioration study also carried out to define microorganisms classes found in the samples.

\section{Results :}

\subsection{Polarizing Microscope (PM) Study:}

Petrographic study for some weathered samples of rock art support revealed that, the granite rock is granular texture and consists of quartz, potash feldspar, plagioclase feldspar, with minor amounts of biotite, hornblende and (iron oxides). Biotite and hornblende represent the 
coloured minerals in the rock; they occur as minor constituents of the rock. Biotite occurs as subhedral to anhedral flakes and show wavy extinction (Fig.5(a)), and the alteration of some biotite to iron oxide (hematite) which stained the rock with brownish colour, the samples contained both zircon and hornblende crystals (Fig.5(b)).The samples exhibit alteration of the biotite to clay minerals (green chlorite) (Fig.5(c)). Quartz occurs asfine to coarse (0.4-1.5 mm diameters) and forms interlocking anhedral crystals filling the interstices between feldspars. It is mostly fresh; however, some of the quartz grains contained wide fractures as a resultof mechanical stress. Marginal corrosion as a result of chemical solutions has been observed in some of the quartz grains. Sometimes the biotite altered to sericite, while albite crystals contained many cracks (Fig.5 (d)). Some of accessory minerals like allanite present in some samples, feldspars are represented by plagioclase, microcline and microcline perthite. The plagioclase is highly weathered to clay minerals and largely replaced by very fine particles of sericite appearing pale grey (Fig.5 (e)). Potash feldspar is represented by microcline, which occurs as fine to coarse subhedral to anhedral crystals; characterized by cross hatching twinning, sometimes occurs as elongated crystals as a result of mechanical strain or stress, with marginal corrosion (Fig.5(f)).Large grain of microcline is strongly altered to kaoliniteas a result of chemical weathering (Fig.5(g)). 
Microcline perthite occurs as subhedral to anhedral crystals, mostly cracked (Fig.5(h)).

Scanning Electron Microscope (SEM) investigation:

Scanning Electron Microscope (SEM) examination of some weathered sample of granite has revealed that; the major deterioration for rock art represented in abundance of soluble salts in addition toa high degree of weathering for the rock as follows; different microcracks which have long and narrow sharp ended cracks, in addition to transgranular and intergranular fractures which caused the disintegration and decohesion among the mineral grains (Fig.6 (a)). Cavities and vugs are very largeand deep inside stone structure and lead to increasing the porosity causing the granite become permeable and accelerate the rateof deterioration (Fig.6 (b)). A widespread coating of different salts is the majorweathering feature such as halite and variedphases of gypsum. Halite crystal usually occurs in cubic form, produce a kind of vuggy pockets (Fig.6(c)), while gypsum phases occur in cluster and distributed inthe cavities and vugs and penetrate towards inside (Fig.6 (d)). Extensive penetration of fungal hyphae inside the stone structure, which caused pitting or alveolar weathering inside feldspars and biotite grains (Fig.6 (e- f)). 


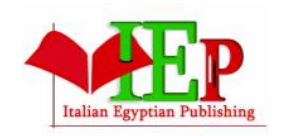

ISSN: 2735-4415

INTERNATIONAL JOURNAL OF

MULTIDISCIPLINARY STUDIES IN ARCHITECTURE AND CULTURAL HERITAGE

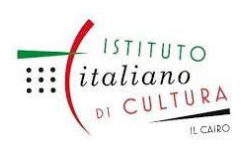

VOLUME 2, ISSUE 1, 2019, 67 - 104.

www.egyptfuture.org/ojs/

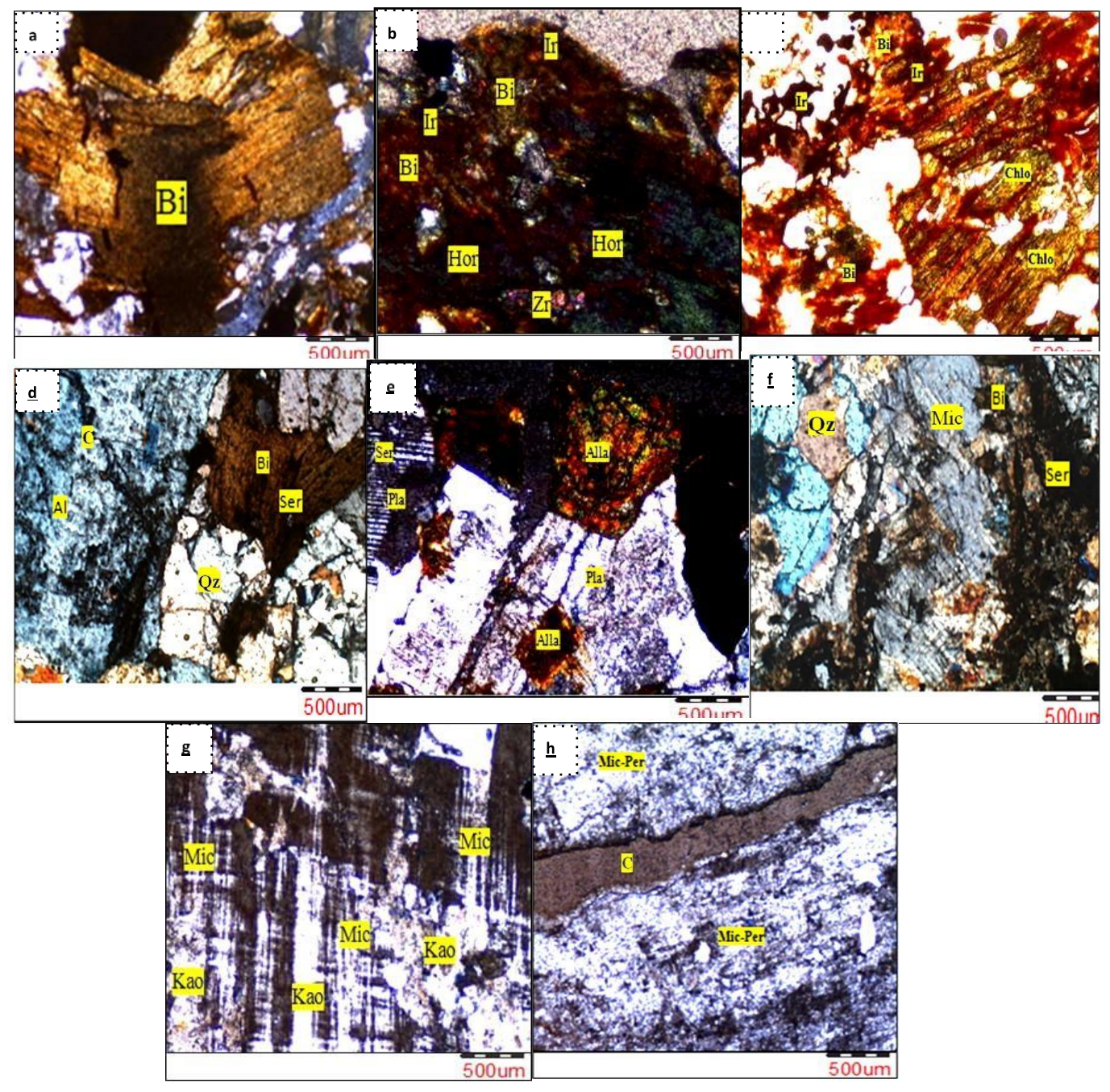




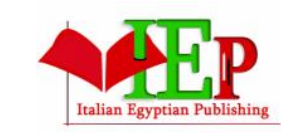

ISSN: $2735-4415$
INTERNATIONAL JOURNAL OF

MULTIDISCIPLINARY STUDIES IN ARCHITECTURE AND CULTURAL HERITAGE

VOLUME 2, ISSUE 1, 2019, $67-104$.

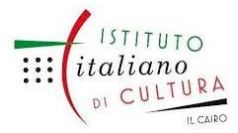

www.egyptfuture.org/ojs/

Fig. 5 The examination of granite samples under polarizing microscope:

(a) Wavy extinction in biotite crystal.(b) Hornblende, zircon and biotite grain altered to iron oxide.

(c) Biotite altered to iron oxide and chlorite. (d) Biotite altered to sericite and albite contains crack.

(e) Allanite and plagioclase altered to sericite. (f) Quartz, microcline and biotite grain altered to sericite. 


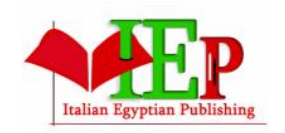

ISSN: 2735-4415

INTERNATIONAL JOURNAL OF

MULTIDISCIPLINARY STUDIES IN ARCHITECTURE AND CULTURAL HERITAGE

$\overline{\vdots \vdots \vdots}\left(\begin{array}{l}\text { istituto } \\ \text { italiano } \\ \text { DI CULT }\end{array}\right.$

VOLUME 2, ISSUE 1, 2019, $67-104$.

www.egyptfuture.org/ojs/

(g) Microcline cross hatching twining altered to kaolinite. (h) Microcline perthite contains crack.

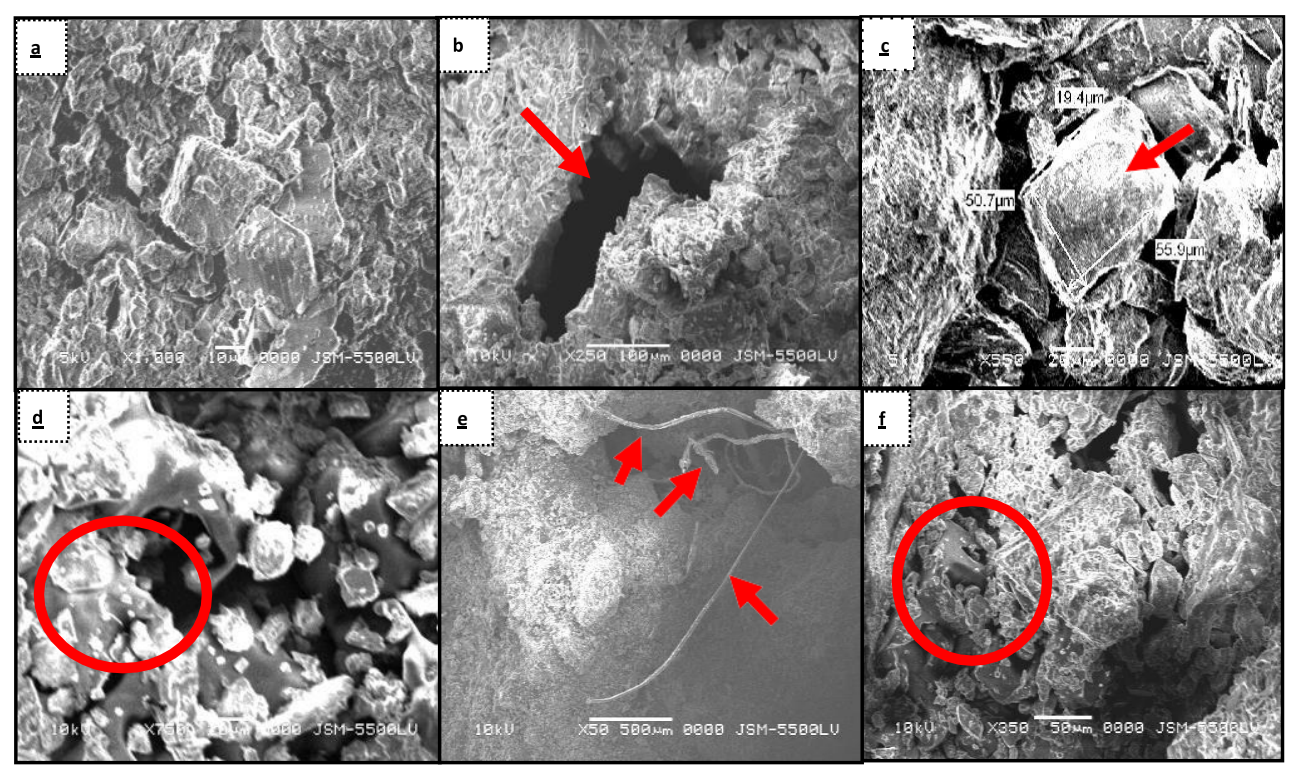

Fig.6 The SEM micrographs of weathered granite samples from rock art support: 
(a) Disintegration and decoheshionof granite grains. (b) Large, deep cavities inside stone structure.

(c) Cubic crystal of sodium chloride.

(e) Fungal hyphate inside stone structure. (d) Crystals of anhydrite and gypsum.

(f) Weathered feldspars with clay minerals.

\subsection{X-Rav Diffraction Analysis (XRD):}

2. X-ray diffraction results of granitesamples (Fig.7 (a-d) \&Table.(1)) have identified, the presence of quartz $\mathrm{SiO}_{2}$ as major mineral in most of the samples, while the minor minerals are represented by feldspars(albite, $\mathrm{NaAlSi}_{3} \mathrm{O}_{8}$ ) and microcline, $\left.\mathrm{KAISi}_{3} \mathrm{O}_{8}\right)$ biotite, $\mathrm{K}(\mathrm{Mg}, \mathrm{Fe})_{3} \mathrm{AlSi}_{3} \mathrm{O}_{10}(\mathrm{OH})_{2}$, Anhydrite, $\mathrm{CaSO}_{4}$, calcite, $\mathrm{CaCO}_{3}$ and halite $(\mathrm{NaCl})$ were represented in weathered samples.

\subsection{Energy dispersive $X$-rav analysis (EDX):}

The results of EDX analysis of granite samples (Fig. 8(a-d) and Table(2)) have indicated that, the granite samples contain high iron $(\mathrm{Fe})$, high concentration of calcium $(\mathrm{Ca})$, high sulfate $(\mathrm{S})$, a presence of $\mathrm{Na}$ and $\mathrm{Cl}$, In addition to the high amount of potassium $(\mathrm{K})$ and Aluminum (Al) and low ratio of $\mathrm{Ti}$ 
INTERNATIONAL JOURNAL OF

MULTIDISCIPLINARY STUDIES IN ARCHITECTURE

AND CULTURAL HERITAGE
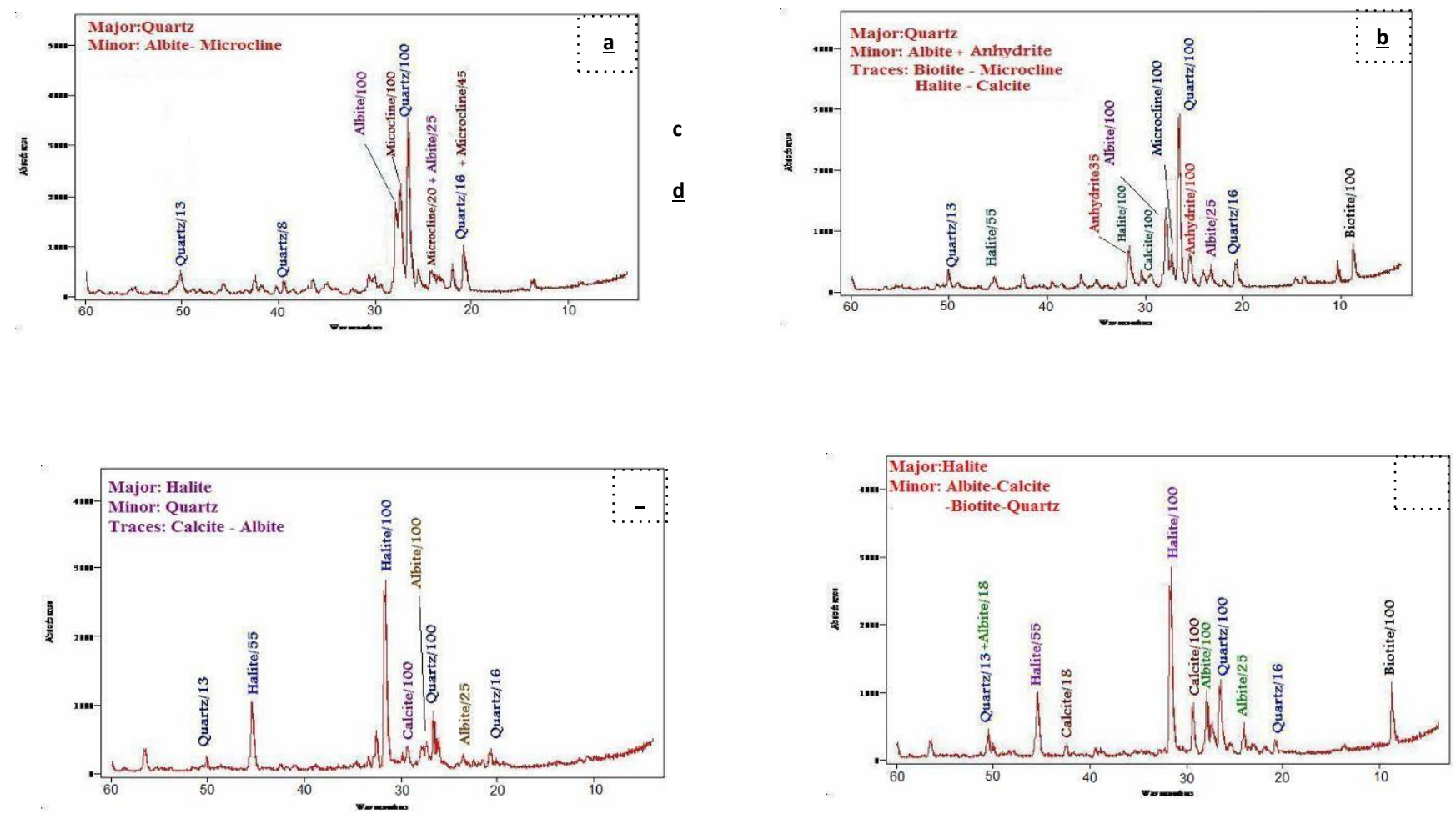
INTERNATIONAL JOURNAL OF MULTIDISCIPLINARY STUDIES IN ARCHITECTURE AND CULTURAL HERITAGE

ISSN: $2735-4415$
VOLUME 2, ISSUE 1, 2019, 67 - 104.

www.egyptfuture.org/ojs/

Figure. 7 XRD patterns of granite samples from unfinished obelisk quarry. 


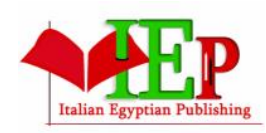

ISSN: $2735-4415$

INTERNATIONAL JOURNAL OF

MULTIDISCIPLINARY STUDIES IN ARCHITECTURE AND CULTURAL HERITAGE

VOLUME 2, ISSUE 1, 2019, 67 - 104.

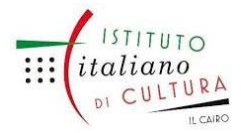

www.egyptfuture.org/ojs/

Table.1 XRD patterns of granite samples

from rock artat unfinished obelisk quarry.

\begin{tabular}{|c|c|c|c|}
\hline \multirow{2}{*}{$\begin{array}{c}\text { Samples } \\
\text { No }\end{array}$} & \multicolumn{3}{|c|}{ Chemical Components } \\
\cline { 2 - 4 } & Major & Minor & Traces \\
\hline A- & Quartz & Albite \& Anhydrite. & $\begin{array}{c}\text { Biotite, Microcline, } \\
\text { Halite \& Calcite. }\end{array}$ \\
\hline B- & Quartz & Albite \& Microdine. & - \\
\hline C- & Halite & Quartz & Albite \& Calcite. \\
\hline D- & Halite & $\begin{array}{c}\text { Albite, Calcite, } \\
\text { Biotite \& Quartz. }\end{array}$ \\
\hline
\end{tabular}
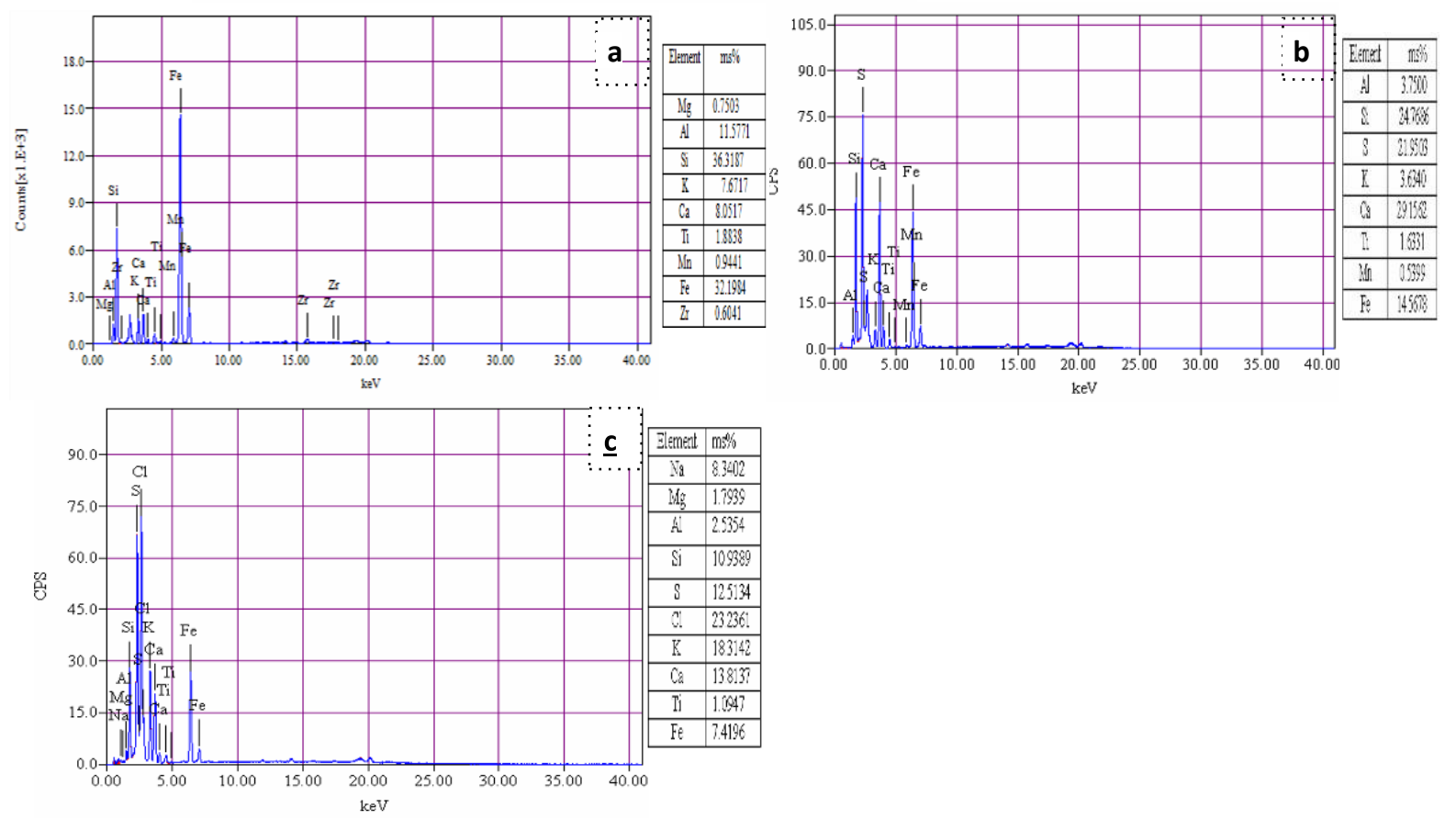


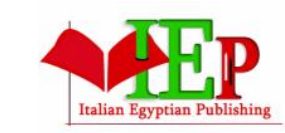

ISSN: 2735-4415

INTERNATIONAL JOURNAL OF

MULTIDISCIPLINARY STUDIES IN ARCHITECTURE AND CULTURAL HERITAGE

Fig.8 EDX patterns of granite samples from unfinished obelisk quarry

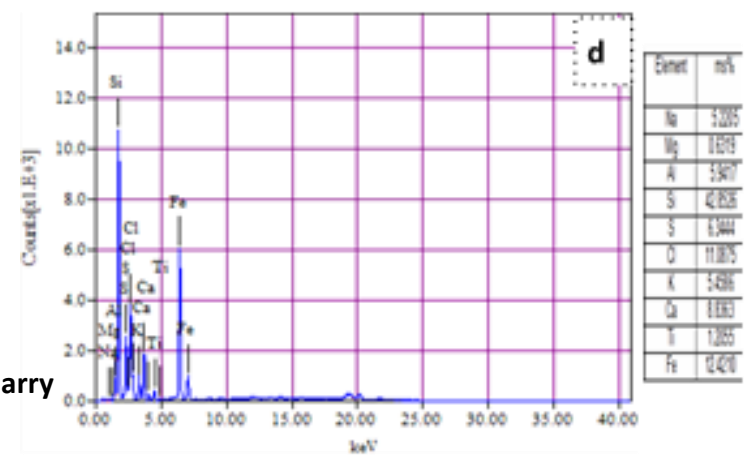

Table.2 EDX patterns of granite samples from unfinishedobelisk quarry. 
INTERNATIONAL JOURNAL OF

MULTIDISCIPLINARY STUDIES IN ARCHITECTURE AND CULTURAL HERITAGE

\begin{tabular}{|c|c|c|c|c|}
\hline $\begin{array}{l}\text { Chemical } \\
\text { Component }\end{array}$ & \multicolumn{4}{|c|}{ S amble No } \\
\cline { 1 - 3 } Percent \% & A & B & C & D \\
\hline Si & 36.3187 & 24.7686 & 10.9389 & 42.8526 \\
\hline K & 7.6717 & 3.6340 & 18.3142 & 5.4586 \\
\hline I.In & 0.9441 & 0.5399 & & - \\
\hline I.Ig & 0.7503 & - & $\mathbf{1 . 7 9 3 9}$ & 0.6319 \\
\hline Zr & 0.6041 & - & & - \\
\hline Ti & 1.8838 & 1.6331 & $\mathbf{1 . 0 9 4 7}$ & 1.2055 \\
\hline Fe & 32.1984 & 14.5678 & 7.4196 & 12.4210 \\
\hline Ca & 8.0517 & 29.1562 & 13.8137 & 8.8363 \\
\hline Na & - & - & 8.3402 & 5.2205 \\
\hline CI & - & - & 23.2361 & 11.0875 \\
\hline S & - & 21.9503 & 12.5134 & 6.3444 \\
\hline Al & 11.5771 & 3.7500 & 2.5354 & 5.9417 \\
\hline
\end{tabular}

2.2. Infra red analysis (I.R):

I.R spectra of black and red pigments from the rock art on granitic bedrock at unfinished obelisk quarry show absorption bands at the following wave numbers: $13546,3409,3200,1625,1618,1384,1381,1092,1030$ and 
INTERNATIONAL JOURNAL OF

MULTIDISCIPLINARY STUDIES IN ARCHITECTURE

AND CULTURAL HERITAGE

1024 as shown in (Fig.(9) and table(3)). By comparison study with, glue albumen, egg-yellow and Arabic gum I.R. stander shows that, the medium which was used in studied rock art was Arabic gum. According to (Ahmed, S.A. \&Abbas, H.K., 2011) theprevious pigments consisted of hematite $\left(\mathrm{Fe}_{2} \mathrm{O}_{3}\right)$ as red pigment and carbon (c), asblack pigment.

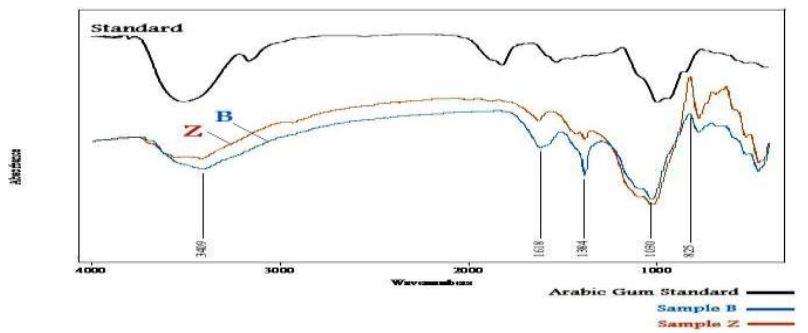

Fig.9 I.R spectra of black and red pigments from rock art at unfinishedobelisk quarry.

Table 3 FTIR results of rock art pigments medium from unfinished obelisk quarry.

\begin{tabular}{|c|c|c|c|}
\hline \multicolumn{3}{|c|}{ Wave Number } & \multirow{2}{*}{ Functional Groups } \\
\cline { 1 - 3 } $\begin{array}{c}\text { Sample B } \\
\text { Black pigment }\end{array}$ & $\begin{array}{c}\text { Sample } \mathbf{Z} \\
\text { Red pigment }\end{array}$ & Arabic Gum & \\
\hline 3409 & $3546-3413$ & $3600-3200 \mathrm{~cm}^{-1}$ & O-H Stretching band \\
\hline 1618 & 1625 & $1650 \mathrm{~cm}^{-1}$ & O-H Bending band \\
\hline 1384 & 1381 & $1480-1300 \mathrm{~cm}^{-1}$ & C- H Bending band \\
\hline 1030 & $1092-1024$ & $1300-900 \mathrm{~cm}^{-1}$ & $\begin{array}{c}\text { C-O Stretching } \\
\text { bands }\end{array}$ \\
\hline
\end{tabular}




\subsection{Isolation and identification microorganisms:}

Microbiological analyses revealed the presence of bacteria and fungi at average contamination levels (Fig.10 (a-h) and Table (4)). For the isolation of fungi, plate count method was used, the plates contained Czapek's agar medium (17).The same method was used for the isolation of bacteria,by using nutrient agar medium (NA) (18). The Isolated fungi were identified at least to the genus level depending on their morphological characteristics using light microscopes according to (19). The fungal strains isolated from the weathered granite belong to the genera; Aspergillus niger, Aspergillus flavus, Alternaria alternate, Paecilomyces carneus, and Cladosporum uredinicola, Also Gram positive- sporing form of Bacillus sp.,Bacillus insolitus, Bacillus alcalophilus, bacteria were identified.

Fig.10 (a) Petrie dishes of bio-colonization.

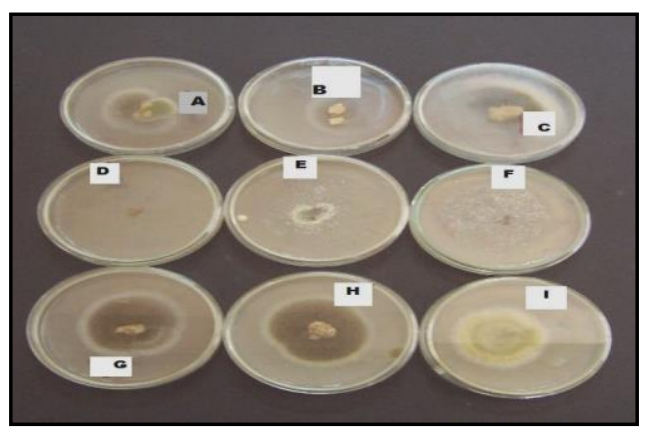


INTERNATIONAL JOURNAL OF

MULTIDISCIPLINARY STUDIES IN ARCHITECTURE

AND CULTURAL HERITAGE

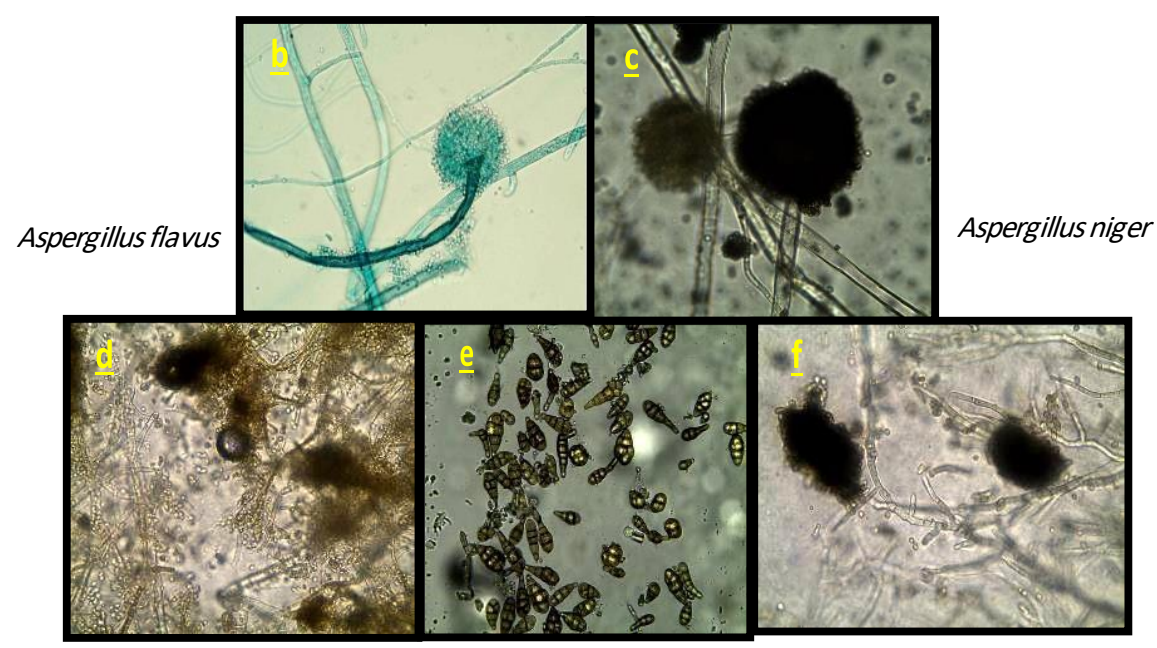

Paecilomyces carneus

Alternaria alternate

Cladosporium uredinicola

Fig.10 (b-f) Fungi isolated from rock art panels at unfinished obelisk quarry.

Fig.10 (g-h) Bacteria isolated from rock art panels at unfinishedobelisk quarry.

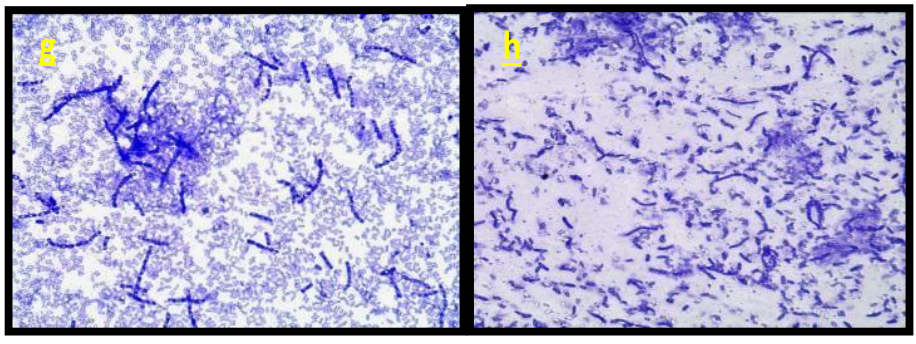

Bacillus insolitus

Bacillus alcalophilus 
Table 4 Microorganisms species isolated from rock art supports from unfinished obelisk quarry.

\begin{tabular}{|c|c|c|}
\hline $\begin{array}{c}\text { Sample } \\
\text { No }\end{array}$ & Fungi & Bacteria \\
\hline 1. & $\begin{array}{l}\text { Asperigellus Flanus, Asperigellus Niger \& Paceilonnces } \\
\text { camells. }\end{array}$ & Bacillus insolitus \\
\hline 2 & 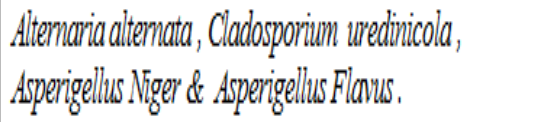 & Bacillus alcalophitus \\
\hline
\end{tabular}

1. Discussion:

The famous unfinished obelisk quarry in Aswan is one of the most important archeological sites, in ancient Egypt it was a source for supplying ancient Egyptian with the raw materials of granite for the establishment their civilization. Rock art at unfinished obeliskquarry carried out on granite surfaces by two previous techniques (paintings and engravings or inscriptions). The rock paintings made of two natural pigments red and black withpaintings media (Arabic gum).

The rock art at unfinished obelisk quarry suffers from several deterioration factors; physical, chemical ,biological and anthropogenic. Anthropogenic deterioration factors include the preparation method of granitesurfaces (polishing or smoothing with a" grinding stone" which leads to variation and difference in its physical properties such as the perceived texture, color and gloss (20) and also generates structural stresses in the rock(21), in the same manner, the nature, the mineral composition, the binder and the method of application of the pigments, all have an 
impact upon pigment response to deterioration factors in the ambient environment.

Liquid pigments are able to penetrate deeper inside the rock, hence they are more resistant to deterioration if compared with dry pigments and those applied as a paste easily peeled off (22), in addition to application the physical enhancement process on rockinscriptions using water and chalk.

Before the previous mentioned factors; the quick discovery during excavations and sudden exposure of rock art panels from burial to aerial environment caused immediate destruction or deterioration after the discovery due to environmental shock and consolidation of rock art later by inappropriate treatment with a solution of Paraloid B 72 in acetone solvent, all the previous measures caused deterioration aspects of rock art such as; fading, peeled off paintings and salt crystallization forms.

Generally, the soil of Aswan area is known to be saline this suggests that, rock art panels buried for thousands of years will eventually become salinized through salt- transporting ground water since the construction of the first dam on the Nile and the High Dam near Aswan .The ancient canal at unfinished quarry represents the main factor of deterioration rock art in the site, as a source of water and saline solutions which lead to the destruction of rock art panels and motivate growing vegetation and higher plants $(23,24,25)$ that also could cause 
some accelerated weathering to rock art in situ. Inhabitants(population) mass around the site promoted the quantity and variety of observable stone deterioration; seepage and leakage water, rising ground water table, visual disfigurement, air pollution that, threaten the rock art in situ. The deterioration phenomena of rock art at unfinished obelisk quarry in Aswan are varied such as; exfoliation, granular disintegration, scaling, cracks, fractures, salt crystallization (efflorescence, sub-florescence), discoloration, in addition to fading, flaking and loss of paintings.

Petrographic Studies have revealedthat; the deterioration of granite was subject to both physical and chemical weathering as follows; both orthoclase and microcline are slightly or strongly altered to kaolinite and sericite. This feature is cleared by the fissures and cracks that are invading the rock, most of biotite and quartz grains make the wavy extinction clear as a result of mechanical stress. Some biotite altered to chlorite or iron oxides as a result of chemical solutions andthe liberation of iron oxides which stained the rock with a brownish color. Moreover some quartz grains contained cracks may be due to the preparation process of rock art surfaces by grinding stones.

SEM Studies have revealed that; the deterioration of granite showed that the collapse of the internal structure of the stone disintegration and decoheshion between grainsas a result of many crystallized salts especially halite, gypsum 
and anhydrite which exhibit macro and microcracks, fissures and pits inside the internal structure of rock, furthermore alteration of feldspars to clay minerals and the growth hayphae of biodeterioration within thestone's pores.

XRD Studies have revealed that; the granitic support of rock art consists of quartz, microcline, albite, biotite as main components in addition to calcite as secondary mineral, some samples also contained anhydrite and halite salts. Feldspars minerals and biotite are maincomponents in granite rocks; anhydrite is assumed to be the result of transformation of the gypsum, which caused the surface layer detachment. Also in this case, both of anhydrite and gypsum mostly may have been associated with seepage water from ancient canal or airpollution. Some authors have specifically postulated that these crusts are formed by combination of sulfates from air pollution and Ca from feldspars (26,27 ). X-ray diffraction patterns also revealed that weathered granite samples contained a high mount of aggressive salt, sodium chloride $\mathrm{NaCl}$ due tosoluble salts from soil in consequence of direct contact and adjacency between granitic bedrock (rock art support) and the water from the ancientcanal recently discovered at site and the ancient egyptian used it to facilitate the transportation granite blocks from the quarry to the Nile (28).

EDX Studies have revealed that; the support is highly weathered by deterioration factors as follow; high iron $(\mathrm{Fe})$ content due to alteration process of 
iron oxides; convertferrous-iron to ferric iron (29) which cause coloration of granite with brown, beige to red colors. A high concentration of calcium (Ca)may be attributed to calcite, originated from decomposition of feldspars. The relatively high sulfate $(\mathrm{S})$ and $(\mathrm{Ca})$ contents in the samples may be attributed to the crystallization of calciumsulphate salts (anhydrite and gypsum). ( $\mathrm{Na}$ ) ionsperhaps attributed to sodic or plagioclase feldspars components in granite, furthermore thehigh concentration of chlorine $(\mathrm{Cl})$ and sodium $(\mathrm{Na})$ in the samples suggested that the degradation of granite was also due to the crystallization of sodium chloride $\mathrm{NaCl}$. On the other hand the results of EDX also revealed that the decrease of silica $(\mathrm{Si})$ content in granite samples and this loss is due to alteration process. In addition to the high amount of potassium (K) and Aluminum (Al) respectively attributed to feldspars content of the rock and the presence of titanium (Ti) and potassium (K) correlated with the content of alumina or alteration processes.

Bio-deterioration Studies have revealed that; the isolated fungi and bacteria from the granitic rock art were of these species: Fungi such as; Aspergillus Niger, Aspergillus flavus, Alternaria alternata, Paecilomyces carneus and Cladosporium uredinicola, bacteria such as; Bacillus alcalophilus and Bacillus insolitus. these genera of microorganisms were cleared by SEM, and their growing correlated with environmental factors and presence of feldspars in 
granite as a source of nutrients for them (30) also they play aggressive role in physical and chemical weathering of rock art through theycontribute to acid dissolution, oxidation, chelation by organic acids or other substances produced by the fungi (31) and physical fracturing induced by root hyphae.

FTIR Studies have revealed that; the medium which was used in rock paintings on thegranitic bedrock at the unfinished obelisk quarrywas Arabic gum.

\section{Suggestions and Recommendations:}

- Re-design development schemes forpopulation mass adjacent to the unfinished obelisk site to minimize their impact upon the archaeological site or move it away.

- Completion the archaeological excavations in the site via systematic methods.

- Re-habitation of rock art site through design site management contains foot paths or walkways, (boardwalks), guidance signs, informative signs, low fencing to guide visitors over a site and barriers around the panels as protective procedures.

- Legislation should forbid theinappropriate methods in archaeological 
- documentation ofrock art by application physicalenhancement process using water, chalk and other substances.

- Recording methodologies should use non-destructive techniques which don't cause damage to rockart being recorded.

- Before conservation procedures of rock art sites, it's necessary to assess the current condition, the risks from humans, natural causes, the environmental pollution and the adjacent setting.

First, before the conservation works begin, it is necessary to prevent the contact with groundwater from the ancient canal and keeping water out of the rock art through change the waterway in the canal or design a pipeline system or using covered drainage.

- Removing and cleaning vegetationand higher plants in the site mechanically and chemically byusing chemical pesticides.

- Consolidation the weak granitic panels with ethyl silicate; Estel $100015 \%$ in white sprit by suitable mean pipette, brushing or Injection (32).

- Removal soluble salts by suitable poultices cleaning with protective layer of long fiber tissue paper(Japanese or hemp) for protecting water sensitive pigments in rock paintings.

Dry biological colonization's mustbe removed from the rock support by 
dry brushing then applying chemical treatment with suitablepesticides to forbid the microorganisms growth in the future.

- Monitoring the site to observe any re-colonization, if this occurs in any substantial way, then repetition oftreatment may be required.

- Applying water diversion system through opening natural drainage lines or drainage channels using sand, cement and the rock on theroof of granitic bedrock for allowingthe water to run off far away from the panels.

- Applying dripline technique using appropriate silicone water repellent on vertical panels to prevent them from direct water erosion (flow) by rains effects.

- Redirecting water emanating from cracks or fissures through using silicone building sealant to fill narrow cracks or fissures, while large ones must be filled with Schlarge foam product then silicone sealant applying (33).

\section{$\underline{\text { References: }}$}

1. Yates, R., Parkington,J.\& Manhire,T.,1990.,: Pictures from the past. Centaur. Pietermaritzburg..

2. Kelany, A., Negem,M., Tohami,A.\&Heldal,T.,2009.,: Granite-quarry survey in 


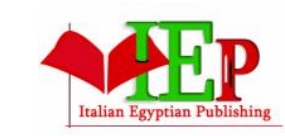

ISSN: $2735-4415$
INTERNATIONAL JOURNAL OF

MULTIDISCIPLINARY STUDIES IN ARCHITECTURE

AND CULTURAL HERITAGE

VOLUME 2, ISSUE 1, 2019, $67-104$.

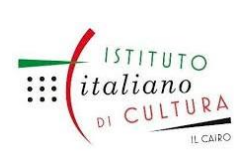

www.egyptfuture.org/ojs/

the Aswan region, Egypt:shedding newlight on ancient quarrying. In Abu-Jaber,N.,Bloxam,E.G.,Degryse,P.and Heldal,T.

(eds.) QuarryScapes:ancientstone-quarry landscapes in the Eastern Mediterranean, Geological Survey ofNorway, Oslo, pp. 85-96.

3. Engelbach,R.A.,1923.,: The problems of the obelisks:from a study of the unfinished obelisk at Aswan.T.F.Unwin, Pub.,London.

4. Kelany,A., 2003.,: Excavation of theunfinished obelisk quarry, unpublished report for the Supreme Council of Antiquities, pp. 1-70.

5. Hawass, Z.,2009.,:The unfinished obelisk quarry at Aswan .In Ikram,S.\& Dadson, A. (eds.) Beyond the Horizon: Studies in Egyptian Art, Archaeology and History in Honour of Barry J Kemp, Cairo, pp.143-164.

6. Chaffee,S.D.,Hyman,M.\&Rowe.M.W.,199 4., :Vandalism of rock art for enhanced photography. Studies in Conservation39,pp.161-168.

7. Ahmed,S.A.\& Abbas,H.K.,2011.,: Deterioration of rock art painting at unfinished obelisk quarry in Aswan.Journal of American Science,Vol .7, pp.275-281.

8. Zezza,F.,2002.,: Non-destructive technique for the assessment of the deterioration processes of prehistoric rock art in Karstic caves the Paleolithic paintings of Altamira (Spain). Protection Conservation of theCultural Heritage of the MediterraneanCities, the Netherlands, pp.377-388.

9. Batchelor, A.,1990.,: Preservation of South African rock art. Report for Human Sciences Research Council. HSRC,Pretoria. 
10. Rosenfeld,A., 1988.,: Rock Art Conservation in Australia. Australian Government Publishing Service, Canberra.

11. Warke,P.A.\& Smith,B.J.,1998.,:Effects ofdirect and indirect heating on the validity of rock weathering simulation studies anddurability tests. Geomorphology 22,El Sevier, pp.347-357.

12. Shahidzadeh-Bonn, N.,Desarnaud,J.,Bertrand,F.,Chateau,X.\&B onn,D.,2010.,:Damage in porous media due to salt crystallization.The American Sic.Physical Society, Vol 81.

13. Bland,W.\& Rolls,D.,1998.,: Weathering: An introduction to the scientific principles. Arnold Publishers, London.

14. Barton, D.C.,1916.,:Notes on thedisintegration of granite in Egypt.Journal of Geology, Vol 24.

15. Vincente, A.M.,Garcia-Talegon ,J.,Inigo, A.C.,Molina,E.\&Rives,V.,1993.,:Weatherin g mechanism of silicated rocks in environment. Conservation of stone \&other Materials, Vol.I, Paris, pp.320-327.

16. Gómez-Heras,M., $\quad$ Smith,B.J.\& Fort,R.,2006.,: Surface temperature differences between minerals in crystalline rocks: Implications for granular disaggregation of granites through thermal fatigue. Geomorphology

78,ElSevier,pp.236-249.

17. Smith,N.R.\& Dawson,V.I.,1944.,: The bacteriostatic action of rosebengal in media used for plate count of soil fungi. Soil Sci.58,pp.467-471.

18. Seeley,J.H.\& VanDemark, P.J.,1981.,: A laboratory Manual of Microbiology. In: Microbes 
in action. Freeman,W.H.\&Company.USA, (Eds.). San Francisco.

19. Domsch,K.H., Gams,W., Anderson,T.H., 1980.,:Compendium of soil fungi. Vol. 1-2. London: Academic Press.

20. Sanmartín,P., Silva,B.\& Prieto.,B.,2011.,: Effect of surface finish on roughness,color \& gloss of ornamental granites. Journal of Materials in Civil Engineering, AmericanSociety of Civil Engineers,2011.

21. Pope,G.A., Meierding,T.C.\& Paradise,T.R.,2002.,: Geomorphology's role in the study of Weathering of cultural stone. Geomorphology 47, pp.211-225.

Loubser,J.H.N., 1991.,: The conservation of rock paintings in Australia and its applicability to South Africa. Navorsingevan by plant growth. Proceeding of the $6^{\text {th }}$ International Congress on Deterioration andConservation of Stone, Torun, Poland, pp.32-44.

22. Mishra,A.K.,Jain, k.k.\&Garg,k.l.,1995.,:Role of higher plants in the deterioration of historic buildings. The science of the totalenvironment 167,pp.375-392.

23. Lisci,M., Monte,M.\& Pacini, E.,2002.,: Lichens and higher plants on stone: a review. El Sevier Science Ltd.

24. Schiavon, N.,1993.,:Micro fabrics of weathered granite in urban monuments Conservation of Stone \& OtherMaterials, Rilem,pp.271-278.

25. Saiz-Jimenez,C.,1993.,: Deposition of airborne organic pollutants on historic buildings. Atmos. 


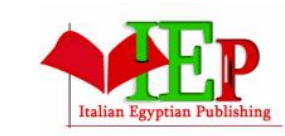

ISSN: $2735-4415$
INTERNATIONAL JOURNAL OF

\section{MULTIDISCIPLINARY STUDIES IN ARCHITECTURE}

AND CULTURAL HERITAGE

VOLUME 2, ISSUE 1, 2019, $67-104$.

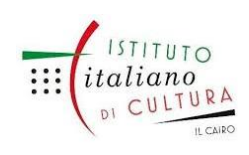

www.egyptfuture.org/ojs/

26. Kelany,A., Parizek, R.R., Alexander,S.S., Gold,D.P., El-Gohary,A., Parizek,K.A. and Walters,E.J., 2007.,: Canal extension confirmed by geophysical surveys, Aswan obelisk quarry, Aswan, Egypt. Bulletin of the Tethys Geological Society 2,pp 35-56.

27. Akarish,A.I.M.,Shoeib,A.S.A.,Nageh,A.\& Dessandier,D.,2012.,: Mechanism and forms of deterioration recoded from thegranitic monumental objects of Alexandrialighthouse, Alexandria, Egypt. Institute forConservation and Restoration of CulturalProperties, Kansai University, Japan, pp.79-94.

28. Rogers,J.R., $\quad$ Bennett,P.C.\&Choi,W.J.,1998.,: Feldspars as a source of nutrients for microorganisms. American Mineralogist, Vol 83, pp. 1532-1540.

29. Viles, H., 1995. Ecological perspectives on rock surface weathering: towards a conceptual model. Geomorphology13, pp.21-35.

30. Abd El- Hakim, Ahmed. El- Badry.,2014.,: Study on deterioration factors of rock arts carried out on the archaeological quarries sites and the methods of treatment and conservation applied on Gabel El- Silsilah and granite quarries at Aswan. Ph.D., Conservation Dep., faculty ofArchaeology, Cairo university.

31. Lambert, D.,2004.,: Introduction to rock art conservation: a guide to the preservation of Aboriginal rock art. Department of Environment and Climate Change, Sydney South, 2007. 